\title{
University-business cooperation: adapting the curriculum and educational package to labor market requirements
}

\author{
Manuela EPURE \\ Academy of Romanian Scientists, Spiru Haret University, Bucharest, Romania \\ office@manuelaepure.com
}

\begin{abstract}
The paper explores the current state of the university- business cooperation at EU, and national level, and it seems that a more structured university- business cooperation might enable universities to adapt their curricula to meet labor market requirements better. A project was designed to address this issue and received funding on a national merit-based competition. During project implementation, exploratory surveys have conducted, findings-based solutions have adopted in practice with promising results. The paper presents the conceptual framework of the Adapt2jobs project, the main activities, and results and how these converged with the current trend in universitybusiness cooperation. The study limits emerged from the scale of the project implementation, and from the response rate registered at the business cohort. Nevertheless, the paper has a clear, practical value which demonstrates that the university- business cooperation can be efficient in curriculum adaptation to the labor market requirements. The study has a real potential for duplication in a wider context, and a comparative analysis is needed to identify good practices in the field, nationally and internationally.
\end{abstract}

Keywords: university-business cooperation, curriculum, skills, competencies, labor market requirements.

\section{Introduction}

Higher education is a crucial sector for the production, dissemination and transfer of economically productive knowledge, innovation and technology in today's knowledge economy (Naidoo, 2010). The current trends in higher education refer to two major components: education process and the innovation in teaching and the graduates' integration on the labor market.

The learning environment is continuously changing, and this requires a constant revision of the teaching methodology and even a new approach from the teacher's perspective. Moreover, today's students are connected 24/7 to the Internet and they explore and learn from it, having almost unlimited access to worldwide knowledge, and that means a lot in terms of learning efficiency (Epure et.al 2015). Teaching and learning in higher education have experienced various innovative practices, which include: (i) a movement to online learning technologies, (ii) blended learning (i.e. the combination of 'traditional learning' and online learning), both at course level and programme level, and (iii) innovative practices in teaching and learning not reliant on technology, such as student-centred and project-based learning.

A recent study (Brenann et al., 2014) reveals the fact that higher education plays an important role in achieving the EU 2020 strategic objectives. The development and implementation of innovations in higher education systems have an impact on all the systems elements: components, relationships and functions. All stakeholders will benefit of 
all these systemic changes. Four main outcomes of innovation in higher education emerge: (i) the vision behind and the use of new technologies represent enablers of innovative practices, rather than innovations per se; (ii) the use of new technologies appears to be a facilitator of the transition from a department-centred vision to a student-centred vision of education; (iii) innovation often stimulates an accelerated development of partnerships between Higher education institutions and other organisations, especially businesses; (iv) innovations in higher education illustrate well two general key aspects of the innovation process: 'doing new things' and 'doing existing things better'.

Most of the time academic freedom and autonomy are claimed to create a lack of responsiveness to the needs of external stakeholders and unwillingness to collaborate with actors in other forms of organisations (Amaral et al., 2003; Shattock, 1999). As a consequence of the above-mentioned ideas, academics consider curricula to be dynamic processes in which the teacher and student can act as 'co-constructors of knowledge' (Fraser and Bosanquet 2006). Students should develop new patterns of thinking (Bratianu, 2007) in concordance with these above mentioned trends and to enhance their intellectual capital potential (Bratianu, 2009).

What types of courses higher education study programmes offer to the undergraduates is essential for their future career, especially because most of them have no work history or work experience to rely on and make up for the lack of skills. Still, the question lingers: what prevents education providers from adjusting the curricula so that it may match the labour-market requirements? This leads us back to McKinsey's metaphor of parallel universes. (McKinsey, 2012) As long as no cooperation exists between university and business, no one could say for sure what a young graduate should know in order to find a job. How can one otherwise account for the astounding discrepancy between what the education providers think on the one hand, and what graduates and employers discover that it is the case? According to McKinsey's report, 74\% of higher education providers were confident that the curricula prepared students for the labour market, while onlyonly 35$38 \%$ graduates \& employers .

This means that the process should begin from the top to the bottom, not the other way round. Firstly, surveys should be conducted among employers and only then should the results be used as the basis for future course design and delivery. The findings of the surveys conducted so far show that the essential skills cherished by the employers are interpersonal skills (team-working and communication skills), computer skills, adaptability to new situations, foreign language skills, commercial entrepreneurial skills (EU Skills Panorama, 2014) . The digital society we have been inhabiting for quite a while, requires that universities should adapt to the technological innovations that have been unleashed. First of all, they should promote knowledge by achieving greater involvement of all actors in society. In a knowledge-based society, it is vital for universities to open up communication channels with those affected by their activities and with the whole society at large.

There is no doubt about it: future starts today and we, the education providers, need to be part of it. That means to understand the challenges, to assume an active role in designing the teaching and learning processes in order to equip the young generation with new skills and competencies, which will help them better integrate in the knowledge-based digitized society. In fact, the key question that we need to ask ourselves is: what do our students need to learn today to be prepared for tomorrow? (Vasilescu et al., 2013). 


\section{Literature review}

A systematic literature review was performed to understand the state of current studies on two important topics: university-business cooperation and innovation in higher education, with emphasis on the curriculum design according to the labor market requirements.

Tabel nr.1 Summary of literature review

\begin{tabular}{|c|c|}
\hline Authors/papers & Summary overview \\
\hline \multicolumn{2}{|l|}{ University-business cooperation } \\
\hline Bramwell and Wolfe, 2008 & $\begin{array}{l}\text { entrepreneurship education (teaching and research), staff and student } \\
\text { mobility and internships, cooperative education; } \\
\text { cooperation in curricula design } \\
\text { commercialize knowledge produced by qualified research scientists, as } \\
\text { well as generating and attracting talents and providing formal and } \\
\text { informal technical support with local industry }\end{array}$ \\
\hline Landry et al., 2010 & $\begin{array}{l}\text { knowledge transfer activities such as collaboration on patents, teaching, } \\
\text { publications, informal exchanges and contribution to spinoff formation }\end{array}$ \\
\hline Boardman \& Ponomariov, 2009 & research partnerships \\
\hline $\begin{array}{l}\text { Gibney, Copeland and Murie, } \\
2009\end{array}$ & $\begin{array}{l}\text { involvement of business representatives in university board structures } \\
\text { or vice versa etc. }\end{array}$ \\
\hline Bathelt, Kogler \& Munro 2010 & $\begin{array}{l}\text { science parks, business incubators, spin-offs (sponsored or } \\
\text { unsponsored) }\end{array}$ \\
\hline $\begin{array}{l}\text { Audretsch, Aldridge \& Mark, } 2011 \\
\text { Smilor, O"Donnell, } \\
\text { Stein and Welborn, } 2007 \\
\text { Clarysse, Tartari and Salter, } 2011\end{array}$ & $\begin{array}{l}\text { innovation accelerators, } \\
\text { high technology centers } \\
\text { technology transfer offices }\end{array}$ \\
\hline Guerrero \& Urbano, 2010 & interdisciplinary centers and co-operation networks \\
\hline $\begin{array}{l}\text { Adams, 2009; Wonglimpiyarat, } \\
2010\end{array}$ & $\begin{array}{l}\text { From a focus on managing knowledge and establishing strong links with } \\
\text { well-established companies in the early years, to a focus on technology } \\
\text { and infrastructure management, entrepreneurship and new start-ups, } \\
\text { as the collaboration matures }\end{array}$ \\
\hline Smilor et al., 2007 & $\begin{array}{l}\text { Proactive approach to development } \\
\text { Research excellence and promotion of spinout companies and } \\
\text { entrepreneurial start-ups } \\
\text { Presence of a catalyst research university, organization and/or role } \\
\text { model }\end{array}$ \\
\hline Mars and Rhodes, 2012 & $\begin{array}{l}\text { Existence of student entrepreneurship programs } \\
\text { Entrepreneurial teaching methodologies, having role models and } \\
\text { reward systems }\end{array}$ \\
\hline \multicolumn{2}{|l|}{ Innovation in Higher Education } \\
\hline Yakovleva \&Yakovlev 2014 & Interactive teaching methods, competence based approach, \\
\hline Fry, Katteridge, Marshall, 2009 & $\begin{array}{l}\text { Understand student learning, } \\
\text { Planning teaching and learning, } \\
\text { Curriculum design and development } \\
\text { Teaching and learning for employability }\end{array}$ \\
\hline Brown \& Atkins, 2002 & $\begin{array}{l}\text { Lecturing - skill, studies on lecturing effectiveness } \\
\text { Small group teaching } \\
\text { Experiential learning } \\
\text { Problem-solving strategies }\end{array}$ \\
\hline Nicolaides, 2012 & $\begin{array}{l}\text { Innovative teaching and learning methodologies } \\
\text { Simulation and role-playing } \\
\text { Problem- based learning } \\
\text { Innovative practice model }\end{array}$ \\
\hline
\end{tabular}




\begin{tabular}{|l|l|}
\hline $\begin{array}{l}\text { Bidabadi,Nasrisfahani, Hollahi, } \\
\text { Khalili, 2016 }\end{array}$ & $\begin{array}{l}\text { Effective teaching methods in higher education } \\
\text { Requirements defining curriculum and teaching resources } \\
\text { Student-centered learning and problem based learning }\end{array}$ \\
\hline $\begin{array}{l}\text { EU 2014 Report on New modes } \\
\text { of learning and teaching in higher } \\
\text { education }\end{array}$ & Modernization of Higher Education \\
\hline Henard, Leprince-Ringuet,2009 & $\begin{array}{l}\text { Quality teaching in higher education } \\
\text { Impact and Quality Assurance of Quality Teaching }\end{array}$ \\
\hline
\end{tabular}

Some interesting conclusions emerged from the literature review:

- University -Business cooperation is still in early stage of development in Europe, there still barriers to be overcome and it is a strong need to attract and keep business representative focused on specific activities with mutual benefits. Universities are engaged in various activities with business, from research results commercialization to knowledge transfer and teaching entrepreneurial skills.

- Higher Education experiences new challenges in term of modernization, integration of new ICT technologies in teaching and learning. HE plays an important role in achieving the EU2020 objectives and strategies, and therefore system innovation is needed. New pedagogical approaches are embraced to generate high level learning effectiveness and to provide graduates certain competencies and skills that can ensure them competitiveness on labor market.

Learning from others' experience is the first step in improving current work; therefore, the paper explores the status of the University Business Cooperation (UBC) at national and EU level and presents the outcomes of a project -Adapt2jobs- that illustrates the cooperation between university and business in one particular activity: curriculum design and course materials development to ensure that graduates' skills and competencies meet the labor market requirements.

\section{University Business Cooperation (UBC) - brief overview}

A recent UBC Study (Davey et al. 2011)- revealed the fact that the cooperation between HEIs and business in Europe is still in the early stages of development.

In the US and Canada, the cooperation between universities and business involve a wide range of initiatives, from public to private engagement, and mediated by different organizations, professional associations or private foundations. For example, Skills for America's Future is a government-led effort to build "partnerships with industry, labor unions, community colleges and other training providers in all 50 states"(The Wihite House, 2010). Another initiative is The Startup America Partnership is an independent, privatesector coalition of major corporations, advisors, funders, service providers and mentors working to dramatically increase the prevalence and success of American entrepreneurs. The Business Higher Education Forum (BHEF) is an organization of senior business and higher education executives that are working to advance innovative solutions to US education and workforce challenges. It is composed of CEOs, college and university presidents, and other leaders, and it aims to address issues fundamental to global competitiveness. There are a multitude of cases of curricular adaptation as the result of exposure to cooperation with businesses outside of the curriculum per se. For example, the curriculum is adapted in cooperative (co-op) education programs to include students' work placements in the course structure, in Univeristy of Waterloo, University of British 
Columbia. So, UBC in US and Canada seems to be driven by : availability and stability of financial resources, availability of excellent human resources, a favourable environment for education, research, innivation and entrepreneurship, regional development needs, institutional culture of collaboration, research, entrepreneurial education, technology commercialization.

European UBC is influenced by a large number of factors including the perception of benefits coming from UBC as well as barriers to and drivers of UBC. Moreover, situational factors such as age, gender, years at the HEI, years in business, type of HEI and country also influence the extent of UBC undertaken. Despite this complexity, UBC can be increased by focussing on appropriate UBC strategies, structures and approaches, operational activities and framework conditions (Davey et al.2011). Approximately, 40\% of academics are not engaged in UBC at all, 20\% of academics undertake only a low extent of UBC whilst only $40 \%$ of academics undertake a medium or high extent.

\section{Adapt2jobs- a valuable teaching and learning experience}

The Adapt2jobs (The adaptation of the curriculum and the educational package to the job market requirements (www.adapt2jobs.ro) project has been initiated as relying on the idea of tackling the university-business cooperation in a new and innovative framework, namely involving business representatives in the curricula and courses syllabus design. Based on own research results along with UBC status in Europe and Romania, we focused our creative efforts on one of the eight ways in which HEIs and business environment can cooperate: we named it "curriculum development and delivery".

The purpose of the project was to raise quality in higher education by better correlating curricula with the labor-market requirements, and by facilitating access to academic studies via the new e-learning technologies. We believe, however, that these two directions should be supplemented by directly involving students in the decision-making process, at least in what concerns certain aspects of the courses. The benefit of the project is that the student is supposed to assess, make a decision and pass on his conclusions, becoming aware of his responsibility not only for his own career, but also for his peers (Epure et al 2015).

At the beginning of the project's implementation, a brainstorming session was organized aiming to identify the core of skills and competencies that employers expected to find on graduates entering labor market. Participants came from different industry and education areas, being a diverse and well represented group of stakeholders, such as: university and high school teachers, students, media representatives, employers associations (The Association of Romanian Businessmen), researchers on education, HR staff of important employers, headhunting companies, all together being interested to identify what competencies and skills are required on the job market and what profile the successful candidate should have (Epure et al.2015). Also, a survey was conducted among future graduates to explore their perceptions on skills and competencies they acquired during their study years and how they could exploit them as competitive advantage on labor market (fig.1). 


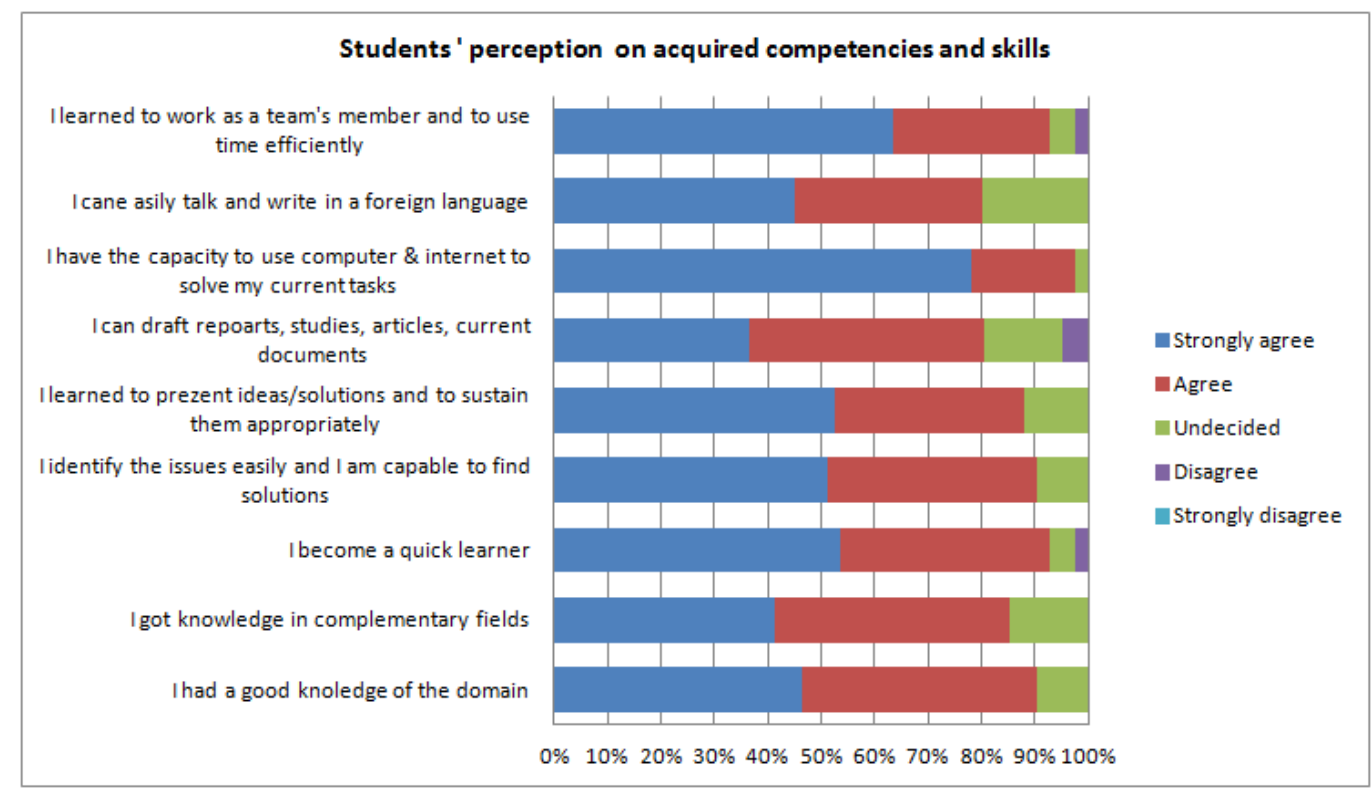

Fig.1 Students' perception on acquired skills and competencies

Source: author's own research.

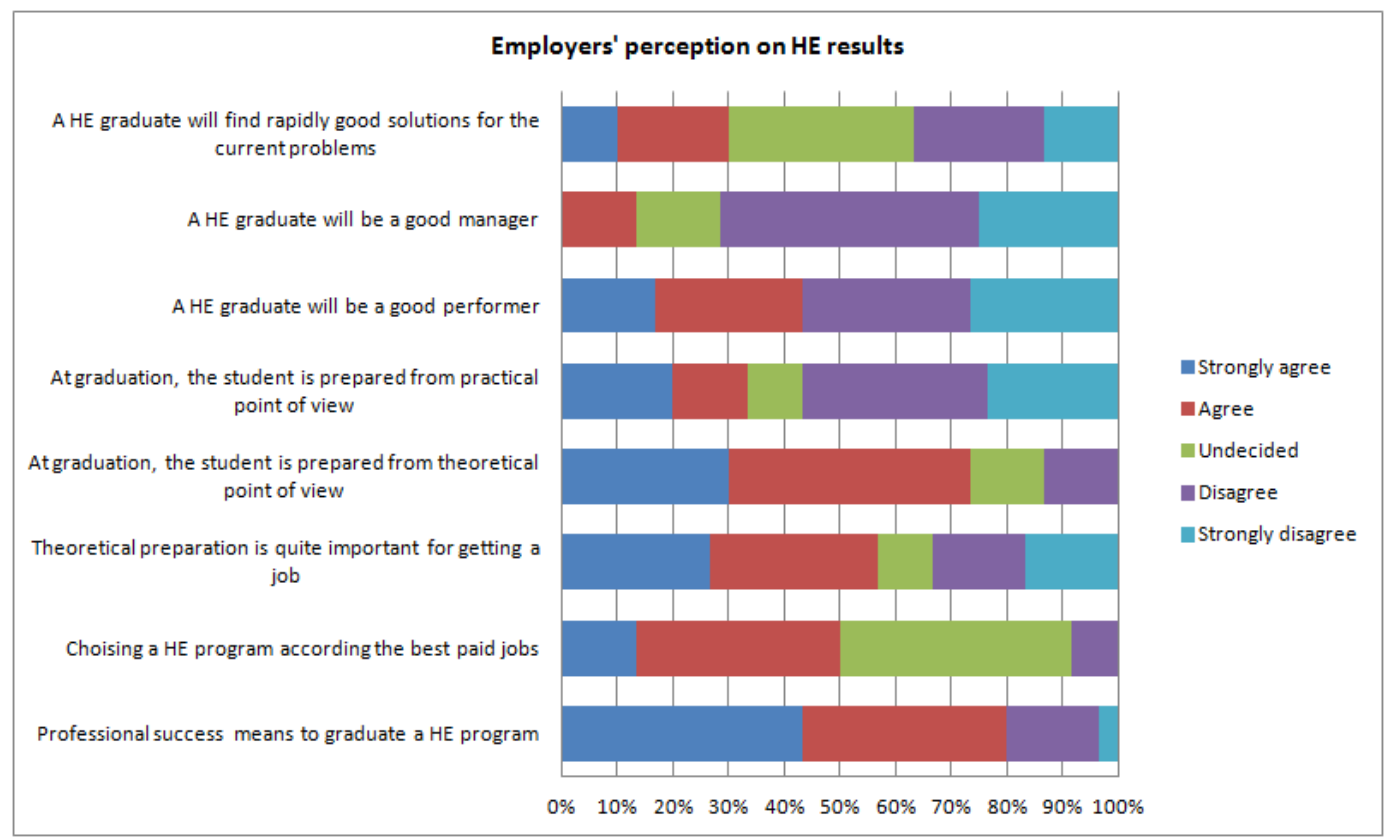

Fig.2 Employers' perception on graduates performances

Source: author's own research.

At the same time, a similar survey was conducted among employers, looking for their perspective on how HE graduates skills and competencies (fig.2) were meeting their expectations. Interesting analysis rose from our collected data (Epure et al.2015, Epure, Mihaes 2015, Epure, Bacalu, 2015, Epure, Vasilescu 2016), and it shows a serious gap between what students think they have learned and what employers want to receive from a young HE graduate, candidate to a job.

The curricula were enriched with seven new courses, in three domains: architecture, social sciences and economics. Based on employers' expectations, courses 
materials were elaborated to serve the main purpose: building those competencies and skills which are needed on the labor market. The course materials were designed for each module, by an interdisciplinary team, tested on students via an online platform (www.adapt2jobs.ro) and improved based on students' feedback. (Fig.3) For each lesson it was developed a series of intermediary assessment tools (quizzes, exercises, case study etc)(Fig.3) aiming to consolidate the acquired knowledge and to encourage learners to look for deeper insights.

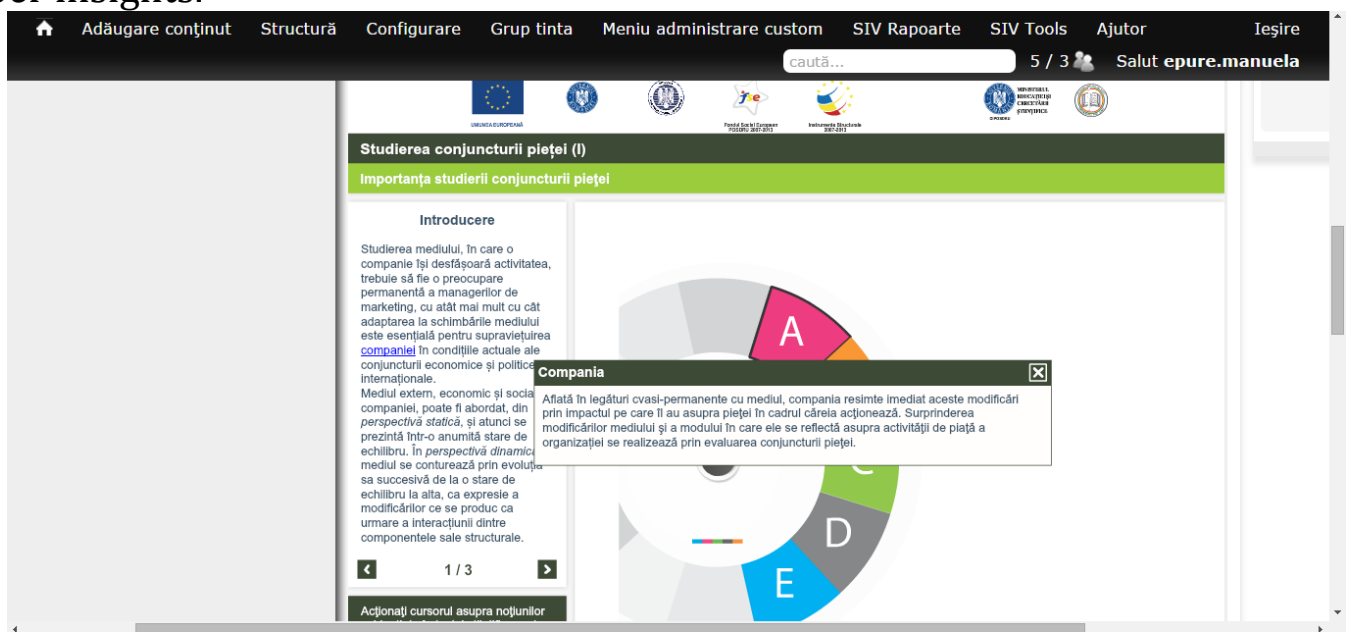

Fig. 3. A sequence from the course The study of the market conjuncture

Source: author's access into www.adapt2jobs.ro.

Encouraged by the results achieved so far, the teams of experts have participated in a brainstorming session organised to explore the project's sustainability paths in the short and in the long run. Our team was made up of experts who come from various fields: pedagogy, ICT, economics, foreign languages, architecture, social sciences, with much experience in higher education.

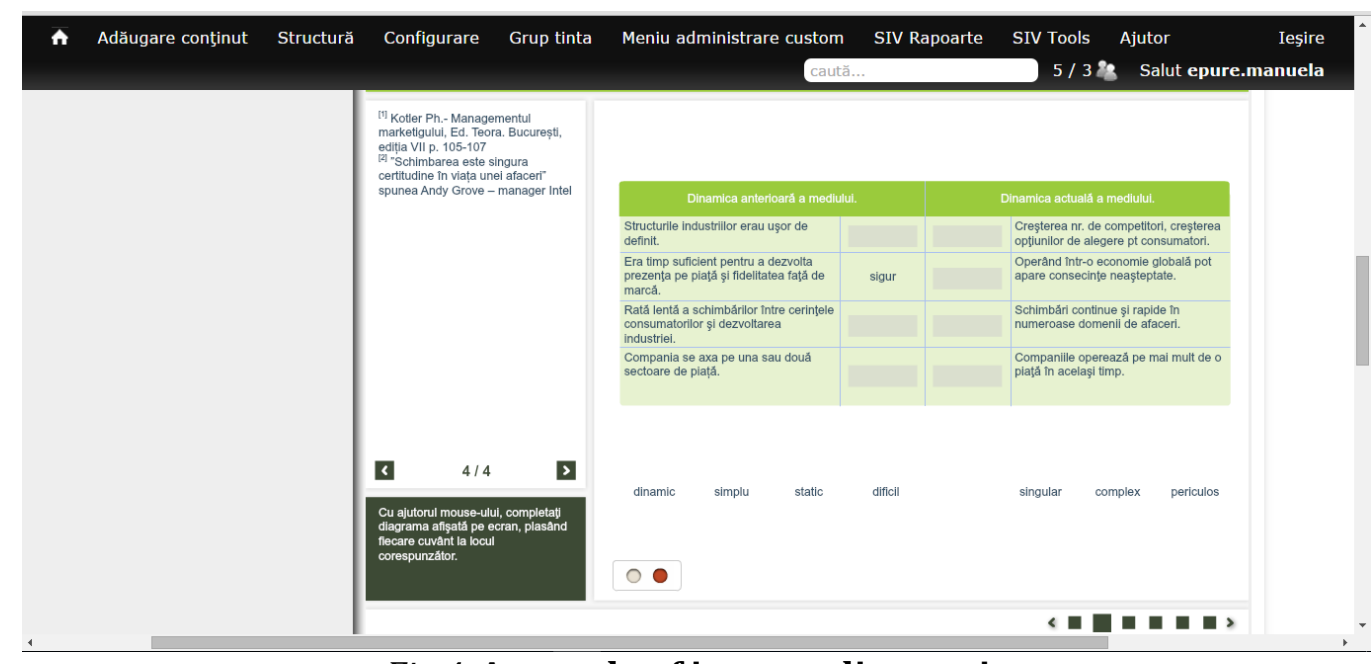

Fig.4. A sample of intermediary quiz

Source: author's access into www.adapt2jobs.ro.

Also, a feedback survey was conducted among students and the most relevant outcomes are: the courses should be tailored to students' learning profile(fig.5); the 
learning experience should be challenging and fun; the visual elements and the interactivity are extremely useful to keep students focused and to attract their attention and make them curious; good learning results are possible only if learners are convinced to stay connected at least 50 minutes per session; learning effectiveness should be constantly assessed because the students' learning profile from one generation to another is constantly changing, course delivery methods should meet students expectations (fig.6).

PICBE $\mid 346$

\begin{tabular}{|c|c|c|}
\hline Respondents marked S- high extent & Freudencies & sobs. \\
\hline Non-response & 63 & 36.05 \\
\hline Learnang [atsditive memory] & 21 & $15.4 \%$ \\
\hline Learning [Visual memory] & 72 & $41.1 \%$ \\
\hline Learning [Understanding] & 21 & $16.3 \%$ \\
\hline Learning [Anaivucal approach] & 43 & 24.65 \\
\hline Learning [Synthetic approach] & 48 & 27.45 \\
\hline Total & 175 & \\
\hline
\end{tabular}

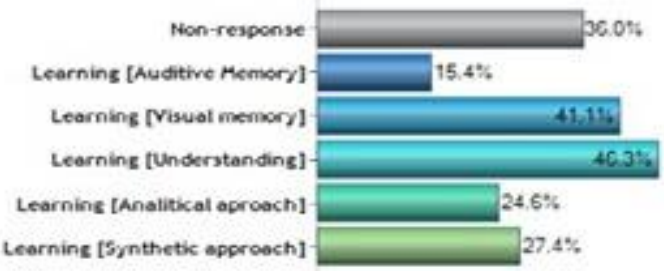

Fig.5. The learning profile of students involved in the pilot study

\begin{tabular}{l|c|c|} 
& Frequencies & $\%$ Obs. \\
\hline New skills (No) & 65 & $37.1 \%$ \\
\hline New skills (yes) & 110 & $62.9 \%$ \\
\hline Broadening my horizon (No) & 103 & $58.9 \%$ \\
\hline Broadening my horizon(Yes) & 72 & $41.1 \%$ \\
\hline Deepening previous learning (No) & 121 & $69.1 \%$ \\
\hline Deepening previous learning(Yes) & 54 & $30.9 \%$ \\
\hline A better diploma(No) & 138 & $78.9 \%$ \\
\hline A better diploma [Yes) & 37 & $21.1 \%$ \\
\hline \multicolumn{1}{|c|}{ Tota } & 175 & \\
\hline
\end{tabular}

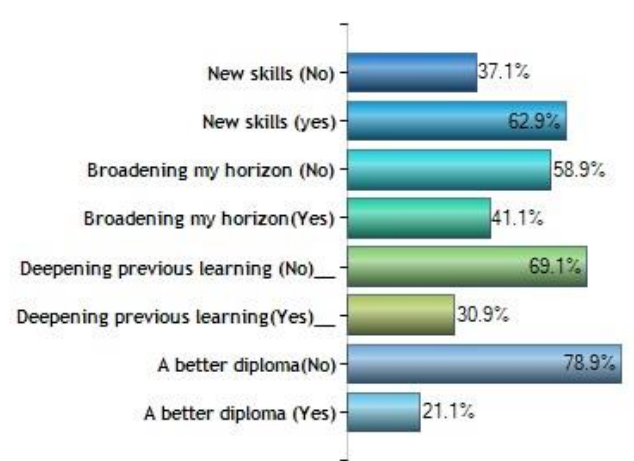

\section{Fig. 6 Students' expectations from a new course content delivery methods (Adapt2jobs)}

Source: author's own research.

The inquiry into the way students generally learn reveals the appropriateness of computer-based instruction for our students, as well as the fact that the digitized courses have been appropriately designed, for at least several reasons: the visual elements prevail; the hyperlink texts, included in the course content in order to explain the key concepts, are more than useful for students; the practical exercises inserted immediately after a theoretical concept/method is introduced, help students to link theory with practice. The feedback study we conduct among students aims at identifying how the student's learning profile influences their evaluation of the digitized courses in what regards the scientific content of the courses and their objectives, the visual and multimedia elements that support the learning process, the usefulness of highlighting the key concepts, the need of teacher's help, the linking of theory with practice, or the effectiveness of the intermediary assessment

\section{Conclusion}

The cooperation of higher education with the industry is needed to be encouraged and supported by appropriate mechanisms, including motivational ones. It is important to understand that are diverse activities that can be developed in partnership and outcomes 
will occur, having an important impact on all stakeholders involved (students, academic staff, employers, society etc .). When it comes about cooperation in curriculum development and deliver, attention should be focused on students' learning profile, course content and delivering methods and skills and competencies acquired. Therefore, the partnership must include three "actors": student, teacher and employer, and looking to build synergies in all their future endeavors.

\section{References}

Adams, S. B. (2009). Follow the Money: Engineering at Stanford and UC Berkeley During the Rise of Silicon Valley. Minerva, 47, 367-390.

Amaral, A. (2003). The higher education managerial revolution? Dordrecht: Kluwer Academic Publishers.

Audretsch, D., Aldridge, T. and Mark, S. (2011). Social capital building and new business formation: a case study of the Sillicon Valley. International Small Business Journal, 29(2), 152-69.

Bathelt H., Kogler D. F. and Munro A. K.A (2010). A knowledge-based typology of university spin-offs in the context of regional economic development, Technovation, 30(9-10), 519-532.

Bidabadi, N., Nasrisfahani, A., Hollahi, A. and Khalili, R. (2016). Effective teaching methods in higher education: requirements and barriers. Journal of Advances in Medical Education \& Professionalism, 4(4).

Boardman, P. and Branco L. (2009). University researchers working with private companies. Technovation, 29(2), 142-153.

Bramwell, A. and Wolfe, D. A. (2008). Universities and regional economic development: the entrepreneurial University of Waterloo. Research Policy, 37(8), 1175 - 1187.

Bratianu, C. (2007). Thinking patterns and knowledge dynamics. In D. Remenyi (Ed.). Proceedings of the $8^{\text {th }}$ European Conference on Knowledge Management (pp.152156), Consorci Escola Industrial, Barcelona, Spain, 6-7 September 2007. Reading: Academic Conferences and Publishing International.

Bratianu, C. (2009). The frontier of linearity in the intellectual capital metaphor. In C. Stam (Ed.). Proceedings of the European Conference on Intellectual Capital (pp. 97-103), Inholland University of Applied Sciences, Haarlem, The Netherlands, 28-29 April 2009.

Brennan, J, Broek, S, Durazzi, N, Kamphuis, Bregtje, Ranga, Steve (2014). Study on innovation in higher education: final report. European Commission Directorate for Education and Training Study on Innovation in Higher Education, Publications Office of the European Union, Luxembourg. ISBN 9789279350818, retrieved from http://eprints.lse.ac.uk/55819/

Brown, G . and Atkins, M. (2002). Effective teaching in higher education, London: Routledge, Taylor \& Francis e-Library.

Clarysse, B., Tartari, V. and Salter, A. (2011). The impact of entrepreneurial capacity, experience and organisational support on academic entrepreneurship. Research Policy, 40(8), $1084-1093$.

Davey, T., Baaken, T., Galán-Muros, V. and Meerman, A. (2011). Study on the cooperation between Higher Education Institutions and Public and Private Organisations in Europe. European Commission, DG Education and Culture. Brussels 
http://ec.europa.eu/education/tools/docs/uni-business-cooperation_en.pdf.

Epure, M., Vasilescu, R.E. and Mihaes L. (2015). Adapt2jobs a new learning ecosystem, Conference Proceedings, The International Scientific Conference eLearning and Software for Education, Bucuresti,

Epure, M., Vasilescu, R.E. and Mihaes, L(2015). Adapt2jobs- a solution for raising accountability and providing project sustainability, ICERI 2015 Proceedings of the 8th International Conference of Education, Research and Innovation (pp.3307-3315), 18-20 Noiembrie 2015, Sevilla, Spania.

Epure M. and Bacalu, F.C.V. (2015). Adapt2jobs - a successful project, EDULEARN 2015 Proceedings of the $7^{\text {th }}$ International Conference on Education and New Learning Technologies (pp.7575-7584), 6-8 July, 2015, Barcelona, Spania.

Epure M. and Mihaes L. (2015). Adapting teaching and learning to the labour market requirements - a Romanian case study, EDULEARN 2015 Proceedings of the $7^{\text {th }}$ International Conference on Education and New Learning Technologies (29112919), 6-8 July, 2015, Barcelona, Spania.

Epure M. , Mihaes L., Gray P.F. and Baicu C. (2015). Blended learning in Higher Education : a view from within, ICERI 2015 Proceedings of the 8th International Conference of Education, Research and Innovation (pp.1325-1332), 18-20 Noiembrie 2015, Sevilla, Spania.

Epure M. (2016) Looking to the future - Adapt2jobs project is just the beginning, G, INTED2016 Proceedings of the $10^{\text {th }}$ International Technology, Education and Development Conference (pp.4252-4262), Valencia, Spain. 7-9 March, 2016, Publisher: IATED.

Epure M. and Vasilescu, R.E.(2016). A comparative study on students' and employers 'perception on competencies and skills acquired to access the job market, pp 111-126, Revista de Pedagogie, year LXIV, nr.1, 2016, ISSN 0034-8678

*** EU Skills Panorama (2014) Employability and skills of higher education graduates Analytical Highlight, prepared by ICF GHK and Cedefop for the European Commission, retrieved from http://euskillspanorama.cedefop.europa.eu/EU 2020 Strategyhttp://ec.europa.eu/europe2020/europe-2020-inutshell/priorities/smartgrowth/index_enhtm

EU 2014 - Report on New modes of learning and teaching in higher education, available online:

Fraser, S. and Bosanquet. A. (2006). The curriculum? That's just a unit outline, isn't it? Studies in Higher Education, 31(3), 269-284.

Fry, H., Katteridge,S. and Marshall, S. (2009). A handbook for teaching and learning in Higher Education. London: Routledge, Taylor \& Francis Group.

Gibney, J., Copeland, S., Murie, A. (2009). Toward a "New" Strategic Leadership of Place for the Knowledge-based Economy. Leadership, February. 5 (1), 5-23.

Guerrero, M. and Urbano, D. (2010). "The Development of an entrepreneurial university", in Journal of Technology Transfer, 37, 43-74

Landry R., Saihi M., Amara N. et al. (2010). Evidence on how academics manage their portfolio of knowledge transfer activities. Research Policy, 39(10), 1387-1403.

Mars, Matthew and Rhodes, Gary (2012). 'socially Oriented Student Entrepreneurship: A Study of Student Change Agency in the Academic Capitalism Context", Journal of Higher Education, 83(3), 435.

McKinsey Center for Government (2012). Education to employment: Getting Europe's youth into work http://www.mckinsey.com/insights/social_sector/converting_education_to_employment_in_europe, 
Naidoo, R. 2003. Repositioning higher education as a global commodity: Opportunities and challenges for future sociology of education work. British Journal of Sociology of Education, 24 (2), pp. 249-259.

Nicolaides, A (2012). Innovative teaching and learning methodologies for higher education Institutions, Educational Research , 3(8) pp. 620-626. 2012 Available online@ http://www.interesjournals.org/ER

PICBE | 349

Shattock, M. 1999. Governance and management in universities: The way we live now. Journal of Education Policy, 14 (3), pp. 271-282.

Vasilescu R., Epure M. And Florea N. (2013). Digital literacy for effective communication in the new academic environment: the educational Blogs, Chapter 18 in Social Media and the New Academic Environment : pedagogical challenges, IGI Global , USA, p.375-384.

*** The White House (October 4 2010), "President Obama to Announce Launch of Skills for America's $\quad$ Future" http://www.whitehouse.gov/the-pressoffice/2010/10/04/president-obama-announce-launch-skills-america-s-future.

Smilor, R., O"Donnell, N., Stein, G., and Welborn, R. S., III (2007). The research university and the development of high-technology centers in the United States. Economic Development Quarterly, 21(3), 203-222.

Technopolis Group, University Business Cooperation, 15 Institutional Case Studies on the Links Between Higher Education Institutions and Business, October 2011.

Yakovleva, N. and Yakovlev, E. (2014). Interactive teaching methods in higher education, Pacific Science Review, 16(2014) 75-80, available on www.sciencedirect.com.

Wonglimpiyarat, J. (2010) Commericialization Strategies of Technology: lessons from Silicon Valley. Journal of Technology Transfer, 35(2), p. 233. 